\title{
Learning Barriers of Affirmation Program Students from Papua and West Papua at the Universitas Negeri Jakarta
}

\author{
Abdul Haris Fatgehipon', Saidna Zulfiqar Bin-Tahir ${ }^{2}$, Hawa Hasan ${ }^{3}$, M Chairul Basrun Umanailo ${ }^{4}$ \\ ${ }^{1,3,4}$ Faculty of Social Sciences, Universitas Negeri Jakarta, Jakarta, Indonesia \\ ${ }^{2}$ Education Faculty, Universitas Iqra Buru, Maluku, Indonesia \\ Email: ${ }^{1}$ harisfatgehipon@gmail.com, ${ }^{2}$ saidnazulfiqar@uniqbu.ac.id, ${ }^{3}$ hawaahasan@ gmail.com, ${ }^{4}$ chairulbasrun@gmail.com \\ Correspondence to: Saidna Zulfiqar Bin Tahir, Universitas Iqra Buru, Maluku, Indonesia, Email: saidnazulfiqar@uniqbu.ac.id
}

\begin{abstract}
One of the development problems in Indonesia is the unequal quality of human resources. To catch up with human resources in Papua, the administration of Susilo Bambang Yudhoyono, through the Papua and West Papua Development Acceleration Unit (UP4B), is implementing an affirmative education program. The affirmation program provided opportunities for Public High School graduates in Papua to have the opportunity to continue their education to the best tertiary institutions in Indonesia. Universitas Negeri Jakarta (UNJ) is one of the universities that accept students from Papua with an affirmation program. The preliminary observation results showed that some affirmation program students who studied at the Faculty of Social Sciences of UNJ have problems. Based on the issues, the researchers attempted to explore the learning process of affirmation program students from Papua and West Papua at FIS-UNJ and what are the learning barriers faced by affirmation program students from Papua. The study applied a descriptive qualitative method. The critical informant was the dean of the Faculty of Social Sciences of UNJ. In contrast, the informants were students from Papua and West Papua Provinces who were studying at FIS-UNJ.
\end{abstract}

Keywords

Barriers; affirmation; scholarship; Papua

Article Received: 10 August 2020, Revised: 25 October 2020, Accepted: 18 November 2020

\section{Introduction}

Educating the nation's life and advancing the general welfare are mandates of the preamble to the 1945 Constitution. For more than 73 years of Indonesia's independence, there are still many areas in Indonesia left behind in the fields of education and welfare, one of which is Papua. Papua Land, divided into two regions of Papua and West Papua Provinces, has a diversity of natural and human resources (Bin Tahir, 2017). The number of clans or tribes in Papua is 260 tribes (Mulyadi: 2012), and the average population is not yet prosperous compared to other provinces in Indonesia, especially with the various kinds of conflicts that have occurred in Papua.

The emergence of various conflicts and upheavals in Papua cannot be separated from the low quality of education and welfare. The Papuan people, through the Papuan People's Assembly (MRP), asked the Indonesian government to pay attention to the service and quality of education for indigenous Papuans so that they are not marginalized. To resolve the turmoil in Papua, the central government then gave Papua special autonomy status. Specifically, the Papua Special Autonomy Law states that the goal of Papua's special autonomy is to reduce the gap between Papua and West Papua Provinces and other provinces, improve the people's standard of living and provide opportunities for indigenous Papuans. The values used to implement special autonomy are protection and respect for moral ethics, fundamental rights of the population, such as health and education (Muhammad In Impartial Team, 2000).

One of the articles in the Special Autonomy Law is in favor of education for indigenous Papuans. Article number 56 of Law Number 21, the Year 2001, regarding special autonomy for Papua Province, states that "Every citizen has the right to obtain quality education with the lowest burden on society." In supporting the implementation of Law Number 21 of 2001, the Central Government issued Presidential Regulation Number 65 of 2011, concerning the Acceleration of Development in Papua and West Papua Provinces (P4B) and Presidential Regulation Number 66 of 2011 concerning Units for the Acceleration of Development for Papua and West Papua Provinces (UP4B) stated, among other things, that its main tasks are: "To provide support to the President of the Republic of Indonesia in coordination, synchronization, facilitation as well as controlling and evaluating the implementation of programs to accelerate development in Papua and West Papua Provinces."

The formation of UP4B was based on the objective conditions currently occurring in the Provinces of Papua and West Papua. The education policy made by UP4B is the affirmation program for Higher Education or better known today as the Higher Education Affirmation Program (Adik), which is the government's alignment program for sons and daughters from the $3 \mathrm{~T}$ region and indigenous Papuans (OAP) to obtain higher education in State Universities (PTN) (Firmansyah, 2012). Affirmative action is a positive action that is directly constructive and provides convenience to minority groups. Affirmations can be in the form of compensation or encouraging progress to create an environment that opens up access to individuals where race and gender are no more extended aspects that hinder one's ability to develop (Desmita, 2009).

The affirmation program is one of the programs initiated in the administration of President Susilo Bambang Yudhoyono, intending to accelerate the improvement of human resources in Papua. Papua is rich in natural resources but limited in human resources. In increasing human resources, it is necessary to provide education for the younger generation in 
Papua (Ardian, 2015). The implementation of the Affirmation education program is not only intended so that the best Papuan youth and girls receive a quality education from various universities in Indonesia but what is no less important is that with this Affirmation program, access to quality education can be obtained by all Indonesian people, thus eliminating the issue of dissatisfaction due to educational development policies that do not take sides with indigenous Papuans (Fatgehipon et al., 2019).

Many of the Papuan people think that the Indonesian government only takes natural resources in their territory without paying attention to the health and education development of indigenous Papuans (Rinantanti et al., 2019). The Affirmation Program, apart from having the aim of educating people in all remote, underdeveloped and outermost areas, also aims to build social integration to strengthen Indonesia's national resilience. The Affirmation Program is a tangible form of state concern for the backwardness of education in Papua and other underdeveloped regions.

Through this affirmation program, it is hoped that Papuan students will have the opportunity to continue their studies at the best universities in Java and other cities in Indonesia. In its implementation, the Affirmation Program is held at the 31 best State Universities in various regions in Indonesia. Participants in the Papuan Affirmation program receive a scholarship from the Director-General of Higher Education (DIKTI) of IDR 600-800 thousand per month. The Ministry of Higher Education supports this living allowance for the cost of living for six months (Saputra, 2018). This amount does not include tuition fees for four years, which are given free of charge. Furthermore, it is hoped that the cost of living will be the responsibility of the local government and parents (Kambuaya, 2015).

Based on the results of initial observations, researchers found that some Papuan students who took part in the Affirmation program experienced learning barriers in carrying out the recovery process at the Faculty of Social Sciences of the State University of Jakarta (FIS-UNJ), several students were participating in the Affirmation program which no longer continued their recovery at FISUNJ. This study aims to determine the learning barriers experienced by Papuan students who study at FIS-UNJ and what factors cause the learning barriers they experience while studying at FIS-UNJ. Therefore, this research is fundamental to be carried out to see and evaluate the course of an education policy process carried out by the government regarding the implementation of the Special Autonomy Law Article 56 of Law Number 21 of 2001 concerning Special Autonomy for Papua Province, which states that "Every resident entitled to quality education with the lowest burden on society.

\section{Method}

The research method that the researcher used is descriptive qualitative (Moleong: 2017). The research steps that researchers have carried out at the beginning of the study are building communication relationships with Affirmation Program Students from Papua and West Papua studying at the Jakarta State University.
Researchers have made preliminary observations about their lecture activities and social life while continuing their studies at the State University of Jakarta. The results of observations that researchers got from the Affirmation Program Students from Papua experienced learning obstacles. This obstacle is caused by the difficulty of adapting to the socio-cultural life on campus, boarding houses, and their environment.

Their academic achievement is low; they find it difficult to compete with other students, especially students from Public Middle Schools in Jakarta. To obtain data in this study, the researcher carried out the following data collection stages: First, the researcher distributes a questionnaire or a list of questions, and then the researcher will conduct interviews with key informants, the dean of the Faculty of Social Sciences and FIS lecturers. The core informants are students from Papua, the Student Executive Board, and other student organizations. The data collected were analyzed descriptively using Miles and Huberman's models, namely data display, reduction, and conclusion drawing.

\section{Results and Discussions}

The data regarding the learning barriers to affirmation program students from Papua at UNJ were obtained using qualitative methods through questionnaires and interviews. At the beginning of the study, researchers conducted interviews with several Papuan students who received affirmation scholarships. The researchers distributed questionnaires to students to be filled in by respondents; after that, the researchers then conducted in-depth interviews to answer research problems. The results of the in-depth interview are as follows:

\begin{tabular}{|l|l|l|l|} 
a. & \multicolumn{3}{|c|}{ Informants Cumulative Performance Index } \\
\hline No & Informants & $\begin{array}{l}\text { Domulative } \\
\text { Index }\end{array}$ \\
\hline 1 & $\begin{array}{l}\text { Leila Imanudha } \\
\text { Dimalow }\end{array}$ & $\begin{array}{l}\text { FBS English } \\
\text { Education }\end{array}$ & 2,85 \\
\hline 2 & $\begin{array}{l}\text { Hendrik P. A. } \\
\text { Mandauw }\end{array}$ & $\begin{array}{l}\text { FT Family } \\
\text { Vocational } \\
\text { Education }\end{array}$ & 3,31 \\
\hline 3 & Yafeth HP & $\begin{array}{l}\text { MIPA } \\
\text { Computer } \\
\text { Science }\end{array}$ & $\begin{array}{l}\text { First } \\
\text { Semester }\end{array}$ \\
\hline 4 & $\begin{array}{l}\text { Willy Sam Simai } \\
\text { Dodap }\end{array}$ & $\begin{array}{l}\text { FIP/PGSD } \\
\text { Semester }\end{array}$ \\
\hline 5 & Bili Y Mayor & $\begin{array}{l}\text { FIS Sociology } \\
\text { Education }\end{array}$ & 2,35 \\
\hline 6 & Jisela Nauseny & $\begin{array}{l}\text { Psychology } \\
\text { Education }\end{array}$ & 2,68 \\
\hline 7 & $\begin{array}{l}\text { Thedora Kondaruk } \\
\text { P Sosesa }\end{array}$ & $\begin{array}{l}\text { faculty of } \\
\text { Economics }\end{array}$ & 2,85 \\
\hline 8 & Samuel Doko & $\begin{array}{l}\text { Faculty } \\
\text { Engineering, } \\
\text { Automotive }\end{array}$ & 2,85 \\
\hline 9 & $\begin{array}{l}\text { Yesaya Gebriel } \\
\text { Numberi }\end{array}$ & $\begin{array}{l}\text { FT, PTIK } \\
\text { Semester }\end{array}$ \\
\hline
\end{tabular}

Papuan students who take part in the Affirmation Program have not very bright achievements, even though to get an affirmation scholarship, they have to go through a series of 
selections from district to provincial school levels, but it is miserable that from the data on academic achievement of affirmation program students studying at UNJ, they are not too bright or fair. Of the nine students who became research informants, one student had a cumulative index above 3. A total of 5 students had a cumulative index below 3. 3 informants were still first semester students. From this data, the researcher then conducted interviews with the nine informants and the Deputy Chancellor for Academic Affairs, Deputy Chancellor for Student Affairs, one of the study program coordinators at UNJ, and the Student Executive Board. The results of interviews from Papuan Affirmation Program students can be described as follows:

\section{b. Informant from Students}

\section{Informant 1 (LID)}

The Ministry of Research and Technology manages the Papuan affirmation scholarship to get a Papuan affirmation scholarship through a selection test in Papua. The accepted participants then take the State Defense Education in Makassar, and the government replaces the Papua Makasar flight ticket. Simultaneously, the cost of traveling from Makassar to college is paid by each prospective student. The obstacles encountered in the academic field are cultural adaptation and student learning ethos. Most Papuan students have low learning motivation, so they experience barriers in learning, most of them do not use their study time well. Several lecturers pay attention to advise and inspiration to affirm program students study hard, excel, and do not be lazy.

\section{Informant 2 (HPAM)}

The purpose of continuing to study at UNJ is to raise the family's reputation and good name. The obstacles encountered in continuing education at UNJ Faculty of Engineering, PKK Department are economic problems, the available scholarships are not sufficient for life in Jakarta. Social relations are well established between fellow students and lecturers. The academic achievement obtained by HPAM is above 3.31. After studying at UNJ, he wants to return to Papua to develop Papua in education, which is still limited in the number of teachers in Vocational High Schools. Campus organization is beneficial in forming a spirit of leadership and a spirit of togetherness between fellow students of different origins. Many organizational activities are participated in, such as Volleyball, Karate, Muaythai, and student organization activities such as the Student Executive Board. Even though he is active in the organization, his academic achievement is still good. Suggestions to the government to pay attention to the welfare of affirmative students from Papua by increasing the nominal value of the scholarships to meet the needs for recovery and daily living expenses in Jakarta.

\section{Informant 3 (YPH)}

I studied at the Department of Computer Science, Faculty of Mathematics and Natural Sciences with the hope of gaining knowledge for my self-development in a better direction. I do not experience academic obstacles, as well as constraints on social interactions. Friendships are well established between college friends on campus, as well as friends in boarding houses. The problems I face are financial. The scholarships provided through the affirmation program are not sufficient for my study needs and my life in Jakarta. Financial constraints have become the main obstacle in studying. My hope is for the government to pay more attention to the amount of the Papuan Affirmation scholarship to meet the needs of Papuan students. Life in Jakarta is costly, unlike other cities in Java.

Informant 4, ( $W S S D$ )

My motivation to study at UNJ was to be a good educator. UNJ is a quality educational institution. Affirmation Scholarships are often late in disbursement. We hope that the government pays more attention to affirmative students. The number of scholarships we get is not sufficient for life and college assignments in Jakarta. Not all affirmation program students have a good family economic background. Economic factors are the most significant obstacle faced by affirmation program students in lectures at UNJ. Academic problems that have become obstacles to recovery have not been met. The relationship between classmates and lecturers is very harmonious. The organizational activity that the informants participated in was the UNJ Sports Activity Unit. By participating in sports activities, self-confidence was formed, and I made many new friends. The suggestion to the government is that the nominal value of affirmative scholarships must be adjusted to the living needs of students in Jakarta, and the scholarships should not be late for disbursement.

Informant 5 (BM)

The motive to study at UNJ becomes a teacher who later returns to Papua to build his hometown. I Interest in learning at UNJ because UNJ is located in the capital city of the country. Every time I often see Jakarta on soap operas, films, and television, it is an exciting factor to study in Jakarta. Obstacles in lectures are economic problems, affirmation scholarships provided by the government whose nominal values do not match the needs of life in Jakarta, scholarships are often disbursed late. Many Papuan students who participate in the affirmation program at UNJ have returned to Papua due to financial constraints. Parents who send their children to UNJ think that their children have already received college scholarships and living expenses financed by the government. They do not know if their children in Jakarta experience economic difficulties due to limited costs. Most of those who take the affirmation program experience failures due to economic factors. Those who are successful in college have families in Jakarta or have wealthy parental backgrounds in Papua. The obstacles encountered during college were cultural differences. They felt inferior and discriminated against, different accent languages and skin colors were obstacles for Papuan students in socializing, but these could all be overcome through organizational activities. Organizational activities such as the Student Executive Board greatly assist Papuan students in socializing with various students from diverse ethnic backgrounds in Indonesia. Lots of help and attention was given by our college friends and boarding house owners when we were experiencing financial difficulties. Suggestions to the government to pay more attention to affirmative students from Papua, preferably students from Papua in the dormitory so that they focus on studying, difficulties faced by Papuan students with affirmation programs in getting a place to live that is comfortable, safe, and affordable in terms of costs. 


\section{Informant $6(\mathrm{JN})$}

I continued studying at UNJ because I was interested in the Department of Psychological Education. The obstacle I encountered while studying at UNJ was the problem of social interaction between friends in class. It is still difficult to meet friends outside Papua, mostly in Jakarta. The association is very individual, and in groups, they find it difficult to accept those of different races from them, making it difficult for me to make friends. In the lecture process, the lecture material can be received well, although I also have to deepen the material being taught to not fall behind with other friends.

The most apparent lecture constraints are economic problems. The nominal value of affirmation scholarships is not following the high necessities of life in Jakarta. Many parents in Papua do not know that in Jakarta, the cost of living is more expensive than in other cities in Java, they have difficulty in supporting their children studying in Papua. Many of the students who take the affirmation program drop out of college due to economic problems. Scholarship payments of 6 million per semester are often not paid on time. So that it makes it difficult for students to finance their qualifications, it is recommended that the government adjust the nominal value of affirmative scholarships, especially in Jakarta, because the necessities of life in Jakarta are different from other cities in Java.

Informant 7 (TKPS)

Since graduating from junior high school, I have received a scholarship from the affirmation program to study at the 17th Vocational High School in Ciligon, Banten. He gained a lot of experience and knowledge while being a student at SMK 17 Ciligon. In terms of learning, it is very far felt between education in Papua and Java, at SMK 17 Ciligon already using the E-Learning program, and referring to the 2013 Curriculum, the academic quality and discipline in carrying out the professional duties of teachers at SMK 17 Cilegon are excellent, in contrast to teachers in Papua. The motivation to study at UNJ is to become a qualified and professional teacher, wanting to return to devoting knowledge in the land of Papua, which has a backward quality of education. There are no educational barriers while studying at UNJ. The campus environment is very accepting, and social relations are well established between Papuan students and other students from various Indonesian regions. Lecturers often motivate class so that Papuan students succeed in education at UNJ.

The problem it faces is financial problems, the cost of living in Jakarta is prohibitive, it is not enough to meet the needs of life in Jakarta. The suggestion for the government is to pay more attention to the amount of the Affirmation Scholarship fee, which is considered insufficient for students studying in Jakarta. The government should select prospective students who register for the affirmation program because many Papuan students fail or leave college, they do not have a sense of responsibility. Even though they are no longer studying at UNJ. However, they still get affirmation scholarship funds from the government, preferably the ministry of higher education, which routinely evaluates Papuan students who receive Affirmation scholarships, whether they are currently in the learning process or are no longer active in lectures.
Theodora often participates in the Student Executive Board of the Faculty of Economics, according to Theodora. BEM activities are very positive. By participating in BEM activities, self-confidence is built, public communication skills are increasingly felt, a spirit of leadership is formed, and social relationships are broader. Regarding the Papuan student demonstrations at the Palace, there were several students from the UNJ affirmation program who took part in the protest. Still, most of the students who received the affirmation program did not approve of the student demonstration and raised the Morning Star flag at the Palace. Students who took part in the protest at the Palace came from mountainous areas, which in terms of political anthropology were different from students who came from the coast. Students who come from mountainous regions tend to disobey the government, are closed and stubborn.

Informant $8,(S D)$

The purpose of studying at UNJ is to be a useful and useful person. Cultural differences are no longer an obstacle. Since my vocational school has attended SMK YO 17 Ciligon Banten, the main barriers faced are economic problems, small scholarships, and irregular discharge have become obstacles to learning. We often run short of money and borrow money from boarding friends and college friends to eat and go to campus. The organizational activity that was followed was the Student Regiment, and this activity was very useful in building leadership character and selfconfidence.

\section{Informant $9,(Y G N)$}

The obstacles encountered in lectures are that the mastery of the material is far behind compared to students from vocational schools in Java, lecturers provide material regardless of the educational background of students, students from SMK Informatics are certainly more advanced and superior compared to students who come from high school schools, especially those from Papua. It is recommended that specific majors such as informatics engineering education carry out a matriculation program for students who do not have an informatics background. The problem faced by most of the affirmation program students was the problem of slow scholarship funding, which until now, we have not received scholarships. The nominal amount of the scholarship must also be considered and adjusted to the needs and cost of living of each region.

In Jakarta, the cost of boarding houses and meals is expensive compared to other areas. Therefore, the cost of the affirmation scholarship for Papuan students in Jakarta must be higher because the cost of living necessities is higher than in other areas. There are some students of the Papuan affirmation program at UNJ. They do not continue their studies, apart from economic problems due to the problem of failing to adapt to a new culture in terms of language even though they use the same Indonesian language. Still, dialect, accent, and phrases, many are different. For example, Jakarta uses ' $l u$ ' for you and 'gue' for me, which is a distance in communication between Papuan and Jakarta students. There should be education on cultural understanding for Papuan students to better adapt to the campus environment and the community in which they are located. The material given during the orientation of new students is not enough. Weaving togetherness between the various cultures of the archipelago must begin by building 
an understanding of differences to not create misconceptions due to cultural differences.

\section{c. Informants from the UNJ}

When he was still the dean of the Faculty of Mathematics and Natural Sciences, the achievements of the affirmation program students who studied at MIPA UNJ were not too many, and most of them failed to complete their studies at MIPA UNJ. Still, some Papuan students studied at UNJ in the 80-90s eras. They completed their studies and returned to Papua to have a promising career (Suyono, Vice Chancellor for Academic Affairs).

Interview with Dr. Abdul Syukur, M.Pd, when he was dean of the Sports Science Faculty, I saw a lot of Sports Science Faculty students who excel academically, students from Papua if given many opportunities to participate in various sports competition activities, they are increasingly challenged and have good potential, several Papuan students get the chance for the National Training Center at the ASEAN Games and Seagames. Papuan students must continue to be nurtured so that their potential will emerge (Abdul Syukur, Vice-Rector for Student Affairs).

Papuan students studying at UNJ generally get two scholarships, the first scholarship from the central government through the Affirmation Program and the second scholarship from the local government of each district in Papua. Although the main thing for Papuan students studying at UNJ is a cultural adaptation, most of them still under old habits, such as drunkenness, parties, and extravagant, drinking alcohol is not only for male students but also for female students, although not all are like that (Manager of Affirmation Program of UNJ, Udep Darussalam).

Geography Education FIS UNJ has affirmation program students from Papua, academically mediocre. The obstacles faced are the difficulty of adapting to a multicultural campus environment, the need for a cultural introduction program before or after they are accepted as students outside Papua to adapt (Aris Munandar, Head of the Department of Geography Education, FIS UNJ).

Based on the data above, the learning barriers for Affirmation Program students who come from Papua can be divided into two; the first is internal barriers or academic barriers and external obstacles or the outside educational environment.

\section{Internal Barriers}

In general, students from Papua who study at UNJ feel left behind in mastering the material compared to other students, especially those from Java. It is understandable, considering a gap in the quality of education services amongst Indonesian regions. Java, especially Jakarta, has the best quality of elementary, intermediate, and high education, so that high school graduates in Java, especially in Jakarta, are likely to have better quality. The attention and development of Papuan education through Papua's special autonomy status is still far from expectations, it even takes time and serious work to catch up with the backwardness of education development in Papua.
Internally, the informal nine do not mention the existence of racial discrimination in education services at UNJ. Lecturers are fair and do not differentiate from one another. Students from Papua need the attention and motivation given to them by the lecturers. There are lecturers when learning in class takes place, not only providing lecture material but also providing encouragement to pay attention and enthusiasm to learn so that they can compete with students from Java Island graduates.

Intra-campus activities, such as the Student Executive Board (BEM) and Student Activity Unit (UKM), greatly assist Papuan students in carrying out social communication, getting to know other students with different ethnic, religious, and regional backgrounds. Intra-campus activities build self-confidence, solidarity, and leadership for students. The obstacles faced by students from the Affirmation Program from Papua were obstacles in social interaction, so they tended to mingle or group with their fellow Papuans.

\section{External Barriers}

The external obstacles faced by students are problems; First, of Economics, Papuan affirmation program students come from various districts in Papua, with diverse economic and social family backgrounds. The nominal value of the scholarship obtained is one million rupees per month, which is considered incompatible with the needs of life in Jakarta. Affirmation scholarships are paid quarterly and are often late. Students from economically disadvantaged families (Civil Servants, Indonesian National Army, Polri) receive additional remittances from parents. Still, students whose parents are farmers or temporary workers have economic problems. The way they meet their recovery needs and the necessities of life are often owed to friends. Many of them decide to return to their hometowns and do not want to continue their studies because of financial difficulties. It is still rare to find Papuan students who survive in Jakarta by working or doing entrepreneurship. Entrepreneurial and independent mentality must be cultivated among Papuan students who have migrated outside Papua.

Second, the Influence of Political Movements, Papuan students studying at UNJ come from various Papua regions. From the results of the interviews, geographic factors greatly influence a person's political orientation. There were affirmation program students who participated in political activities and participated with various student organizations and NGOs to carry out demonstrations demanding Papuan independence. Most students who were critical and defiant came from the Wamena mountain range, while students from the coastal areas were generally not involved in various separatist political movements. The involvement of students in various political activities causes many to not concentrate on lectures and even fail in the study.

\section{Conclusion}

Based on research data conducted at the State University of Jakarta regarding learning barriers for affirmation students, it was found that learning achievement problems were hampered due to financial constraints, the amount of affirmation scholarships distributed to all students on various campuses in Indonesia was the same. In contrast, the 
expensive level in various regions in Indonesia was different., the results of interviews conducted found that all affirmation program students complained about the scholarships they received were not sufficient for the needs of life and student lectures at UNJ. The cultural differences between Papua and other UNJ students are not an obstacle in the learning process. Even students from Papua admit that they get a lot of social assistance from their fellow students outside Papua and their boarding houses.

The social skills of each individual are different. Some students feel discriminatory behavior, but many get positive experiences and impressions during their studies at UNJ and are in a boarding house environment. Affirmation program students from Papua experience many failures while studying at UNJ. Only a few people have succeeded until they graduate. This should be used as an evaluation material from the campus to find the root causes of why they fail in their studies. The suggestion is that the government should pay attention and always control and evaluate the obstacles and learning outcomes of Papuan Affirmation Program students, many of whom do not carry out the responsibility of implementing the responsibility of education properly. They no longer study but still receive scholarships. The nominal value of the scholarship must be increased so that students from Papua are not burdened by financial problems and economic constraints while studying.

The government must also provide dormitory facilities and health insurance to students. So far, students have complained about the difficulty of getting a decent, comfortable, and cheap place to live in Jakarta. Their scholarships run out by paying boarding money, their scholarships as much as 1 million per month are paid every six months, while the cost of boarding a right boarding house in Jakarta above 1 million Rupiah per month. Most of the affirmation program students support the Unitary State of the Republic of Indonesia. They want to rebuild Papua again, for that they should pay attention to their welfare because they are the potential human resources of Papua in the future

\section{References}

[1] Ardian Bakhtiar Rivai. (2015). Kebijakan Pendidikan Afirmasi. Jurnal Ilmu Pemerintahan: ISSN 2442-5958.

[2] Bin Tahir, S. Z. (2017). Multilingual teaching and learning at Pesantren Schools in Indonesia. Asian EFL Journal, 89, 7494.

[3] Desmita. (2009). Psikologi Perkembangan Peserta Didik. Bandung: Remaja Rosdakarya.

[4] Fatgehipon, A. H., \& Bin-Tahir, S. Z. (2019). Building Students State Defending Awareness in Preventing the Radicalism. International Journal of Scientific \& Technology Research, 8(10), 3536-3539.
[5] Firmansyah Muhammad Arie .(2012). Analisis Hambatan Belajar Mahasiswa pada Mata Kuliah Statistika. Jurnal Online FKIP Universitas Muhammadiyah Tanggerang, Volume : 10 Nomor : 2 Halaman 199.

[6] Imparsial Team. (2000). Oase Gagasan Papua Damai. Jakarta: Imparsial.

[7] Kambuaya Carlos (2015). Pengaruh Motivasi, Minat, Kedisiplinan dan Adaptasi diri Terhadap Prestasi Belajar Siswa Program Afirmaasi Pendidikan Menengah Asal Papua dan Papua Barat di Kota Bandung. Jurnal Volume : 5 Nomor : 2 Halaman : 106 - 208 ISNN: 233390042157.

[8] Moleong Lexy. , Metode Penelitian Kualitatif, 2017, Jakarta. Rosda.

[9] Mulyadi. (2012). Budaya Pertanian Papua Perubahan Sosial dan Strategi Pemberdayaan Masyarakat. Bantul: Karta Media.

[10] Rinantanti, Y., Bin-Tahir, S. Z., \& Suriaman, A. (2019). The Impact of EFL Senior High School Teachers' Performance in Papua, Indonesia toward the Students' English Learning Achievement. Asian EFL Journal, 23(3.3), 431-447.

[11] Saputra Candra (2018). Strategi Adaptasi Sosial Mahasiswa Papua Penerima Beasiswa Afirmasi Dikti di Universitas Riau. Jurnal Online FISIP UNRI,Vol .5 Edisi II Juli -Desember 2018. 